\title{
Micropropagation of the Medicinal Plant Eremanthus erythropappus (DC.) MacLeish
}

\author{
L.F. Rosal, J.E.B.P. Pinto ${ }^{1}$, S.K.V. Bertolucci, L.C.B. Costa, \\ and R.M. Corrêa
}

Departamento de Agricultura, Universidade Federal de Lavras, 37200-000, Lavras, MG, Brazil

Additional index words. Eremanthus erythropappus, in vitro culture, micropropagation, apical shoots, nodal shoots

\begin{abstract}
The aim of the present work was to establish appropriate conditions for the in vitro micropropagation of Eremanthus erythropappus (DC.) MacLeish through shoot multiplication on apical and nodal bud explants. Explants were excised from in vitrogrown seedlings and incubated on Murashige and Skoog medium containing different combinations of 6-benzylaminopurine (BAP) and 1-naphthalene acetic acid (NAA) (for apical buds) and gibberellic acid and NAA (for nodal segments). Proliferation of apical shoots was successfully achieved in the presence of BAP and NAA, each at $1.0 \mathrm{mg} \mathrm{L}^{-1}$, while the elongation of apical shoots could only be attained on medium containing NAA

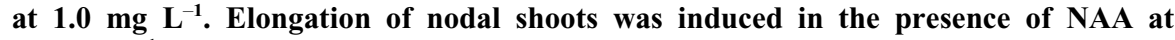
$2.0 \mathrm{mg} \mathrm{L^{-1 }}$. The most suitable medium for inducing root proliferation on explants of E. erythropappus was $\mathrm{NAA}$ at $1.0 \mathrm{mg} \mathrm{L}^{-1}$.
\end{abstract}

Eremanthus erythropappus (DC.) MacLeish (Asteraceae), known in Brazil by the common name candeia, is an arboreous pioneer species distributed from the northeast of Argentina to the northern and eastern regions of Paraguay and Brazil (Carvalho, 1994). The wood of E. erythropappus is physically strong (hard) and is widely employed in the manufacture of stakes, fence posts, timber supports, and boats. The oil of the plant is also of commercial importance, being rich in the sesquiterpene $\alpha$-bisabolol, and has a market value in the order of USD 60/kg (Pérez, 2001). Candeia oil has antiinflammatory properties and is also used in the production of a number of pharmaceuticals employed in dermatology for the treatment of fungal and bacterial infections. Moreover, $\alpha$-bisabolol can replace azulene, a monoterpene found in Chamomilla recutita, as a fixing agent in cosmetic products.

The efficient multiplication and preservation of valuable plants such as E. erythropappus can be achieved through in vitro micropropagation. Micropropagation of wild plants, however, can be labor-intensive and time-consuming owing to the difficulties of removing microbial contamination and of avoiding extensive oxidation of the explants. To overcome such problems, it is preferable to use explants derived from seedlings grown under aseptic conditions (Mantell et al.,

\footnotetext{
Received for publication 2 Mar. 2007. Accepted for publication 29 Apr. 2007.

The authors thank the Conselho Nacional de Desenvolvimento Científico e Tecnológico (CNPq) for financial support.

${ }^{1}$ To whom reprint requests should be addressed; e-mail jeduardo@ufla.br
}

1994). Because no reports are available concerning the in vitro micropropagation of E. erythropappus, we have investigated the conditions required for efficient shoot multiplication on apical bud and nodal explants obtained from seedlings cultivated aseptically.

\section{Materials and Methods}

Plant material. Seeds of E. erythropappus were obtained from mother plants grown in the wild and sterilized using $1 \%$ sodium hypochloride. In vitro germination was achieved by incubating the seeds on MS medium (Murashige and Skoog, 1962) solidified with agar $(0.6 \%)$. The resulting seedlings were employed in all experiments.

Induction of shoots from apical buds. To optimize the induction of shoots, MS medium was supplemented with sucrose $(3 \%)$, agar $(0.6 \%)$, and a range of concentrations of plant growth regulators (PGRs). The medium was adjusted to $\mathrm{pH} 5.7 \pm 0.1$, sterilized by autoclaving $\left(120{ }^{\circ} \mathrm{C}, 20 \mathrm{~min}\right)$, distributed into sterile test tubes, and allowed to cool. Experiments were conducted according to a randomized design and consisted of a factorial matrix $(4 \times 3)$ combining 6-benzylaminopurine (BAP; 0, 0.5, 1.0, and $1.5 \mathrm{mg} \cdot \mathrm{L}^{-1}$ ) and 1naphthalene acetic acid (NAA; 0, 0.5, and $\left.1.0 \mathrm{mg} \cdot \mathrm{L}^{-1}\right)$. Apical buds $(0.5 \mathrm{~cm}$ in length) were excised from sterile 30 -d-old seedlings, placed individually into test tubes, and incubated in the growth room under controlled conditions $\left(26 \pm 1{ }^{\circ} \mathrm{C}, 8 \mathrm{~h}\right.$ dark $/ 16 \mathrm{~h}$ light at $\left.25-30 \mu \mathrm{mol} \cdot \mathrm{m}^{-2} \cdot \mathrm{s}^{-1}\right)$. After $45 \mathrm{~d}$, the number of shoots and the average elongation of the original explants were determined. Nine of the possible 12 combinations of PGRs were assayed in five independent experiments, each involving four replicate tubes for each matrix point. The combinations were (1) 0.0 $\mathrm{BAP}+0.0$ NAA (control); (2) 0.5 NAA; (3) $1.0 \mathrm{NAA}$; (4) $0.5 \mathrm{BAP}+0.5 \mathrm{NAA}$; (5) 0.5 $\mathrm{BAP}+1.0 \mathrm{NAA} ;(6) 1.0 \mathrm{BAP}+0.5 \mathrm{NAA} ;$ (7) $1.0 \mathrm{BAP}+1.0 \mathrm{NAA} ;(8) 1.5 \mathrm{BAP}+0.5 \mathrm{NAA}$; and (9) $1.5 \mathrm{BAP}+1.0 \mathrm{NAA}$.

Induction of shoots from nodal segments. Nodal segments (1.5 cm long) containing two lateral buds were excised from 30-d-old seedlings and placed into MS medium prepared as described above but supplemented with combinations (in the form of a $2 \times 3$ matrix) of NAA (0 and $\left.2 \mathrm{mg} \cdot \mathrm{L}^{-1}\right)$ and gibberellic acid $\left(\mathrm{GA}_{3} ; 0,0.5\right.$, and 1.0 $\left.\mathrm{mg} \cdot \mathrm{L}^{-1}\right)$. Explants were incubated in the growth room for $45 \mathrm{~d}$ under conditions previously described, and the average length of the shoots so formed was determined. Experiments were conducted according to a randomized design, and all six combinations of PGRs were assayed in five independent determinations, each involving four replicate tubes for each matrix point.

Statistical analysis. The effects of the different treatments on shoot induction and development were analyzed by analysis of variance (ANOVA) and Tukey test: differences in mean values were considered statistically significant for values of $\rho<0.05$.

\section{Results}

Development of shoots from apical buds. Shoot multiplication was not observed when explants containing apical buds of E. erythropappus were incubated on medium containing no PGRs or on medium supplemented with NAA alone (Fig. 1, treatments 1-3). On the other hand, the presence of BAP and NAA, each at a concentration of $1.0 \mathrm{mg} \cdot \mathrm{L}^{-1}$ (Fig. 1, treatment 7), was very effective in promoting the formation of axillary shoots. The average number of shoots produced by explants incubated under these conditions was 3.9 , a value that was statistically significantly greater $(\rho<0.05)$ than the $1.6-2.6$ shoots per explant obtained with the other PGR combinations tested. In contrast, only medium supplemented with NAA was able to support the further elongation of the shoot explant (Fig. 2), a maximum average shoot elongation of $3.65 \mathrm{~cm}$ being recorded on medium containing $1.0 \mathrm{mg} \cdot \mathrm{L}^{-1} \mathrm{NAA}$. Medium containing no PGRs, or combinations of NAA with BAP, produced negligible shoot growth. This result was not unexpected as auxins are known to induce shoot growth (Teixeira and Marbach, 2000).

The effect of the dominance of the apical shoot over the axillary shoots and the liberation of this dominance by BAP (Fig. 3) could be clearly observed in the studies with E. erythropappus. Moreover, root formation was inhibited at all concentrations of BAP, whilst intense rooting occurred in medium supplemented with NAA alone, particularly when the concentration was increased from 0.5 to $1.0 \mathrm{mg} \cdot \mathrm{L}^{-1}$ (Fig. 3 ).

Development of shoots from nodal segments. NAA at a concentration $2.0 \mathrm{mg} \mathrm{L}^{-1}$ 


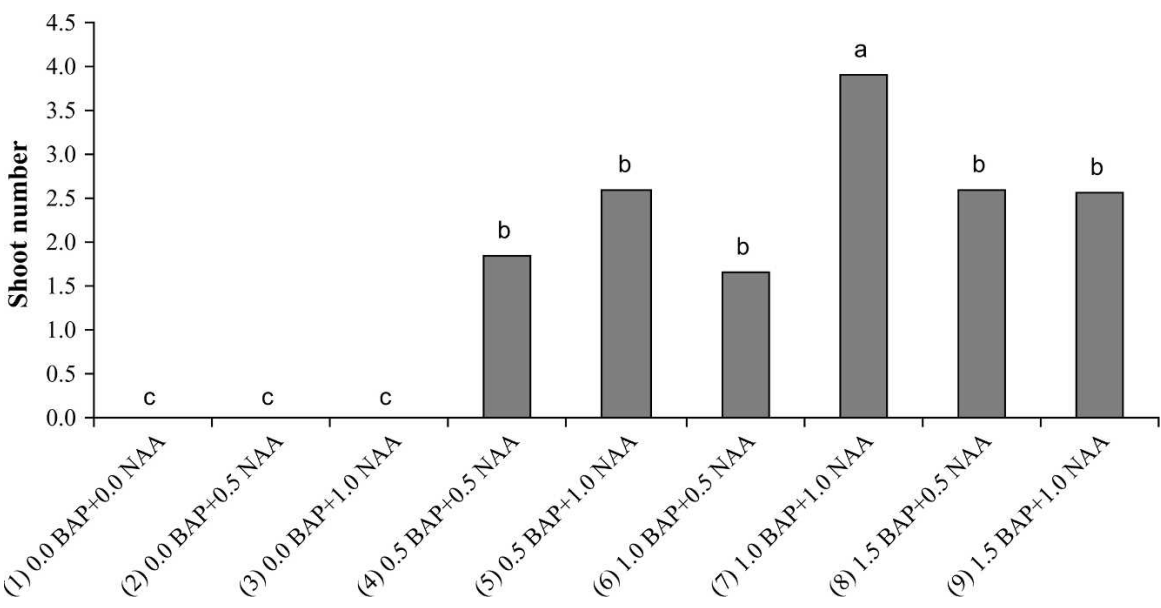

Fig. 1. Number of shoots induced on apical bud explants of Eremanthus erythropappus following $45 \mathrm{~d}$ of incubation on Murashige and Skoog (1962) medium, supplemented with various concentrations (in $\mathrm{mg} \cdot \mathrm{L}^{-1}$ ) of plant growth regulators: (1) control; (2) $0.5 \mathrm{NAA} ;(3) 1.0 \mathrm{NAA} ;(4) 0.5 \mathrm{BAP}+0.5 \mathrm{NAA}$; (5) $0.5 \mathrm{BAP}+1.0 \mathrm{NAA}$; (6) 1.0 BAP + 0.5 NAA; (7) $1.0 \mathrm{BAP}+1.0 \mathrm{NAA}$; (8) $1.5 \mathrm{BAP}+0.5 \mathrm{NAA}$; and (9) $1.5 \mathrm{BAP}+1.0 \mathrm{NAA}$. Mean values labeled with the same lower case letters were not significantly different according to Tukey test $(\rho<0.05)$.

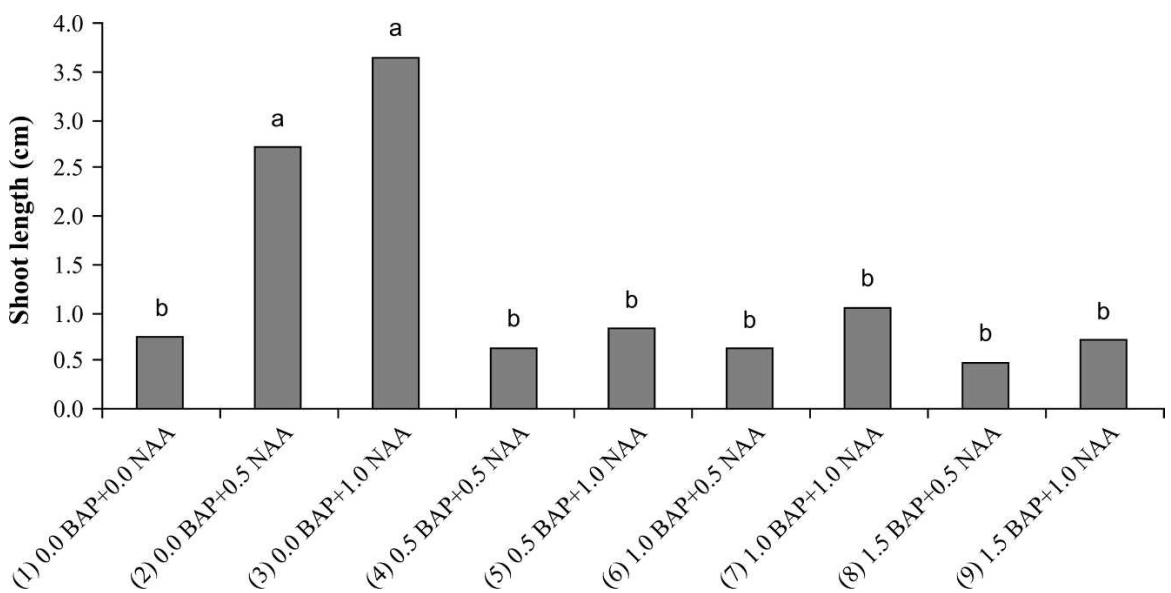

Fig. 2. Length of apical bud explants of Eremanthus erythropappus following $45 \mathrm{~d}$ of incubation on Murashige and Skoog (1962) medium, supplemented with various concentrations (in $\mathrm{mg} \cdot \mathrm{L}^{-1}$ ) of plant growth regulators: (1) control; (2) $0.5 \mathrm{NAA}$; (3) $1.0 \mathrm{NAA}$; (4) $0.5 \mathrm{BAP}+0.5 \mathrm{NAA}$; (5) $0.5 \mathrm{BAP}+1.0$ $\mathrm{NAA} ;(6) 1.0 \mathrm{BAP}+0.5 \mathrm{NAA}$; (7) $1.0 \mathrm{BAP}+1.0 \mathrm{NAA} ;(8) 1.5 \mathrm{BAP}+0.5 \mathrm{NAA}$; and (9) $1.5 \mathrm{BAP}+1.0$ NAA. Mean values labeled with the same lower case letters were not significantly different according to Tukey test $(\rho<0.05)$.

was most effective in promoting the elongation of nodal shoots, with a maximum average length of $1.50 \mathrm{~cm}$ being recorded after $45 \mathrm{~d}$ in culture (Fig. 4). Shoot growth was more pronounced on medium containing no PGRs than on medium supplemented with $\mathrm{GA}_{3}$ alone; indeed, shoots incubated in the presence of $1.0 \mathrm{mg} \mathrm{L}^{-1} \mathrm{GA}_{3}$ attained a length of only $0.40 \mathrm{~cm}$, the smallest mean value obtained in the experiment. Supplementation of the medium with combinations of NAA and $\mathrm{GA}_{3}$ did not improve shoot elongation in comparison with medium containing the same concentration of NAA alone. Furthermore, root proliferation on nodal segments of E. erythropappus was most efficient in the presence of NAA at a concentration of $1.0 \mathrm{mg} \cdot \mathrm{L}^{-1}$ (Fig. 5). The general micropropagation proto- reduced by the presence of high concentrations of the cytokinin. In studies on the micropropagation of Spilanthes mauritiana, Bais et al. (2002) tested low concentrations of auxin (NAA in the range 0-0.04 $\mathrm{mg} \cdot \mathrm{L}^{-1}$ ) and cytokinin (BAP in the range 0 $\left.0.4 \mathrm{mg} \cdot \mathrm{L}^{-1}\right)$ in combination, and showed that shoot multiplication was maximal in the presence of NAA at $0.02 \mathrm{mg} \cdot \mathrm{L}^{-1}$ and BAP at $0.2 \mathrm{mg} \cdot \mathrm{L}^{-1}$.

In contrast, media containing high concentrations of BAP $\left(2-4 \mathrm{mg} \cdot \mathrm{L}^{-1}\right)$ and low levels of NAA $\left(0.1-0.5 \mathrm{mg} \cdot \mathrm{L}^{-1}\right)$ induced shoot formation on apical explants (6.3-6.7 shoots per explant) of $A$. seyal (Al-Wasel, 2000). Moreover, medium containing BAP and NAA at equal concentrations (1.0 $\mathrm{mg} \cdot \mathrm{L}^{-1}$ ) was successful in inducing shoots (5 per explant) in Maclura tinctoria (Gomes, 1999), and the same cytokinin: auxin combination was established in the present study to be optimal for shoot induction in E. erythropappus.

For some species, shoot emergence cannot be induced using combinations of BAP and NAA, and it necessary to employ cytokinin in the absence of auxin. Incubation of apical buds of E. erythropappus in the presence of BAP alone, however, caused hyperhydration of the explants.

The presence of BAP in concentrations between 0.3 and $1 \mathrm{mg} \cdot \mathrm{L}^{-1}$ inhibited root formation in explants of Santolina canescens (Casado et al., 2002), a situation that is similar to that established in the present study for E. erythropappus. In contrast, for cultures of Typhonium flagelliforme, normal roots and shoots were formed in the presence of BAP, whereas inhibition of root growth, together with the formation of abnormal, malformed roots, was observed in the presence of NAA either alone or in combination (Sai et al., 2000).

Because the presence of BAP was essential for shoot induction in cultures of $E$. erythropappus, while combinations of BAP and NAA were not efficient in inducing shoot elongation, a second matrix experiment was carried out using NAA and $\mathrm{GA}_{3}$ with the aim of optimizing the development of nodal buds. However, the presence of $\mathrm{GA}_{3}$ in any concentration was apparently inhibitory to shoot growth. In accordance with this finding, $\mathrm{GA}_{3}$ was found not to be effective in inducing shoot proliferation and elongation in Myrtus communis (Scarpa et al., 2000), and the best response was obtained with medium supplemented with BAP and NAA. This result contrast with that of Figueiredo et al. (2001), who considered the addition of $\mathrm{GA}_{3}$ to be absolutely essential for the elongation of shoots of Rollinia mucosa before transfer to rooting medium. Furthermore, the combination of $\mathrm{GA}_{3}\left(0.5 \mathrm{mg} \cdot \mathrm{L}^{-1}\right)$ and BAP $(0.5$ $\left.\mathrm{mg} \cdot \mathrm{L}^{-1}\right)$ was effective in inducing the elongation of Agave sisalana shoots before transplantation onto rooting medium (Hazra et al., 2002).

Proliferation of apical shoots of E. erythropappus was successfully attained using MS medium supplemented with BAP and 


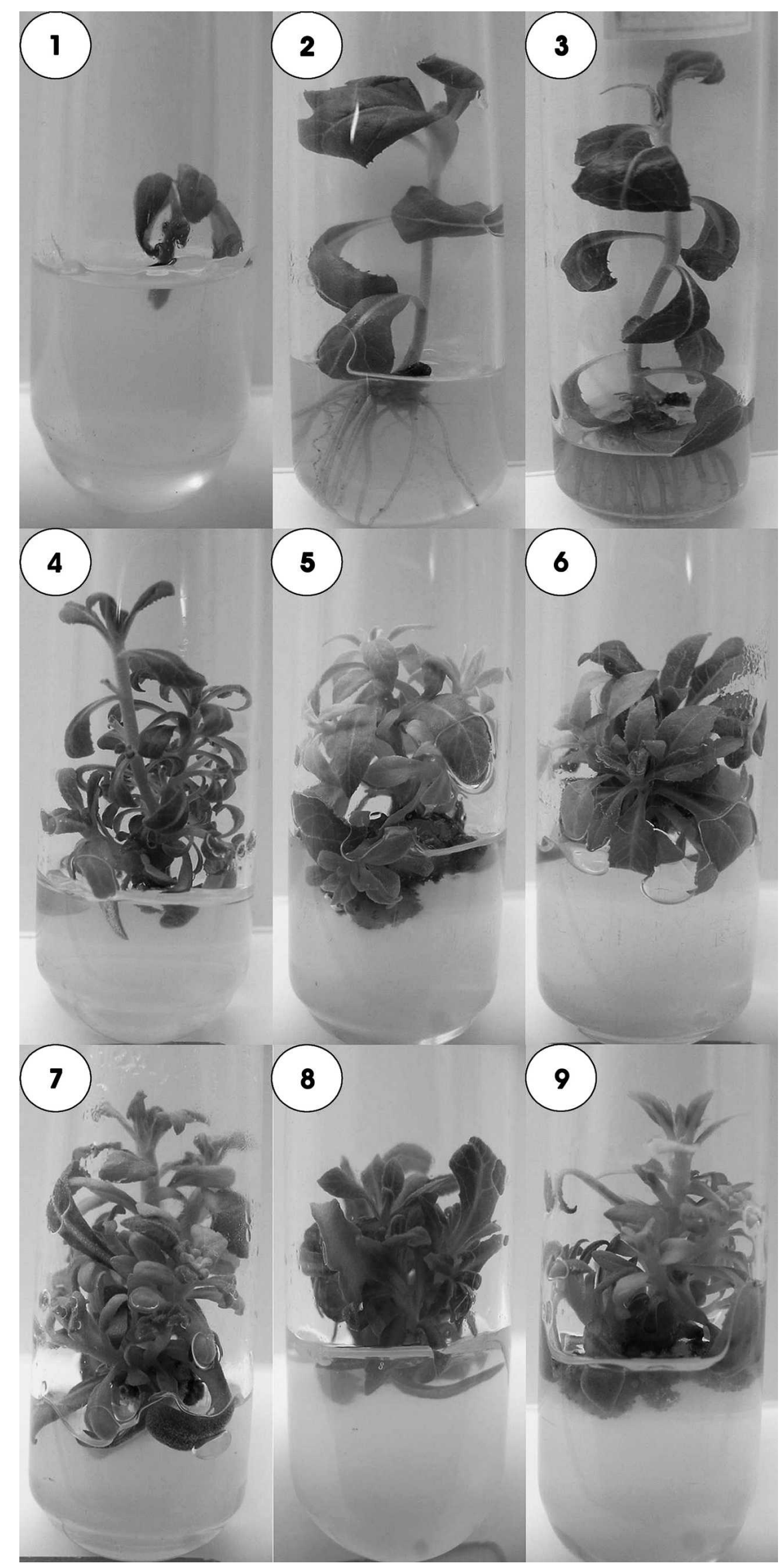

Fig. 3. Development of shoots induced on apical bud explants of Eremanthus erythropappus following 45 d of incubation on Murashige and Skoog (1962) medium, supplemented with various concentrations (in $\mathrm{mg} \cdot \mathrm{L}^{-1}$ ) of plant growth regulators: (1) control; (2) $0.5 \mathrm{NAA} ;(\mathbf{3}) 1.0 \mathrm{NAA} ;(\mathbf{4}) 0.5 \mathrm{BAP}+0.5 \mathrm{NAA} ;(\mathbf{5})$ $0.5 \mathrm{BAP}+1.0 \mathrm{NAA} ;(6) 1.0 \mathrm{BAP}+0.5 \mathrm{NAA}$; (7) $1.0 \mathrm{BAP}+1.0 \mathrm{NAA} ;(8) 1.5 \mathrm{BAP}+0.5 \mathrm{NAA}$; and (9) $1.5 \mathrm{BAP}+1.0 \mathrm{NAA}$ 


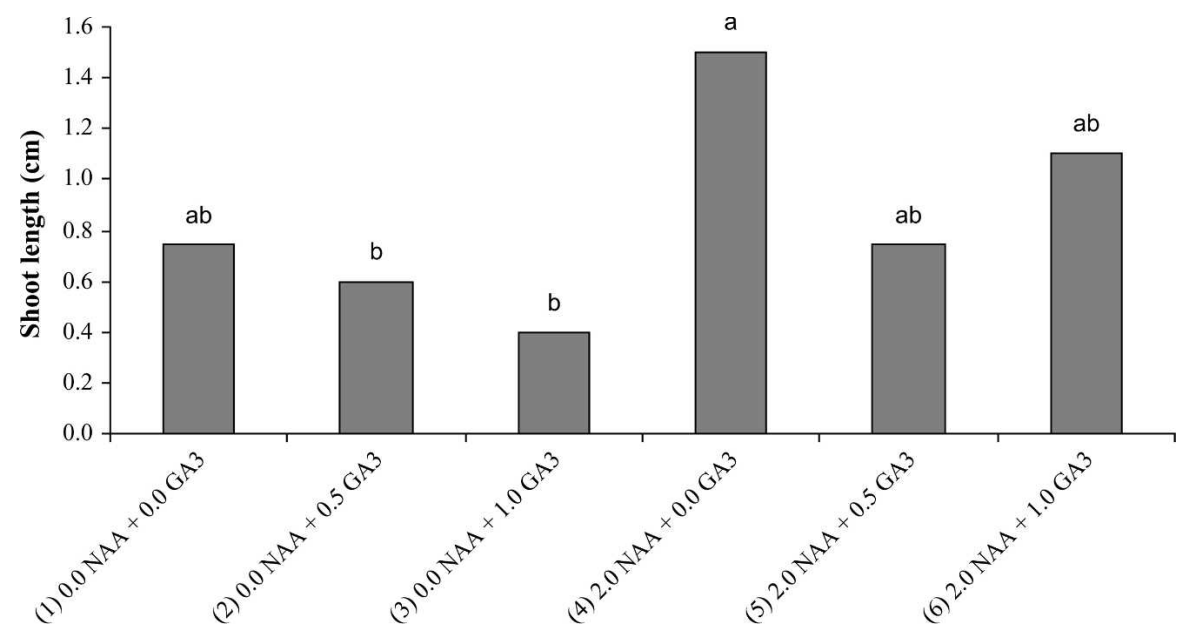

Fig. 4. Length of shoots on nodal bud explants of Eremanthus erythropappus following $45 \mathrm{~d}$ of incubation on Murashige and Skoog (1962) medium, supplemented with various concentrations (in $\mathrm{mg} \cdot \mathrm{L}^{-1}$ ) of plant growth regulators: (1) control; (2) $0.5 \mathrm{GA}_{3}$; (3) $1.0 \mathrm{GA}_{3}$; (4) $2.0 \mathrm{NAA}$; (5) $2.0 \mathrm{NAA}+0.5 \mathrm{GA}_{3}$; and (6) $2.0 \mathrm{NAA}+1.0 \mathrm{GA}_{3}$.
NAA at $1.0 \mathrm{mg} \cdot \mathrm{L}^{-1}$ each. The presence of BAP inhibited the formation of roots but broke the apical dominance and induced the formation of multiple axillary shoots. Furthermore, elongation of apical shoots could be achieved using NAA at $1.0 \mathrm{mg} \cdot \mathrm{L}^{-1}$, while elongation of nodal shoots was induced in the presence of NAA at $2.0 \mathrm{mg} \cdot \mathrm{L}^{-1}$. This finding is very important for the micropropagation of E. erythropappus as the size of the explant determines its survival during the rooting stage and acclimatization (George, 1996). The most suitable medium for inducing the proliferation of roots on explants of E. erythropappus was NAA at $1.0 \mathrm{mg} \cdot \mathrm{L}^{-1}$.

The results presented in this paper, together with the other examples cited, demonstrate the influence of the genotype on in vitro shoot multiplication, as well as the importance of the balance between PGRs.

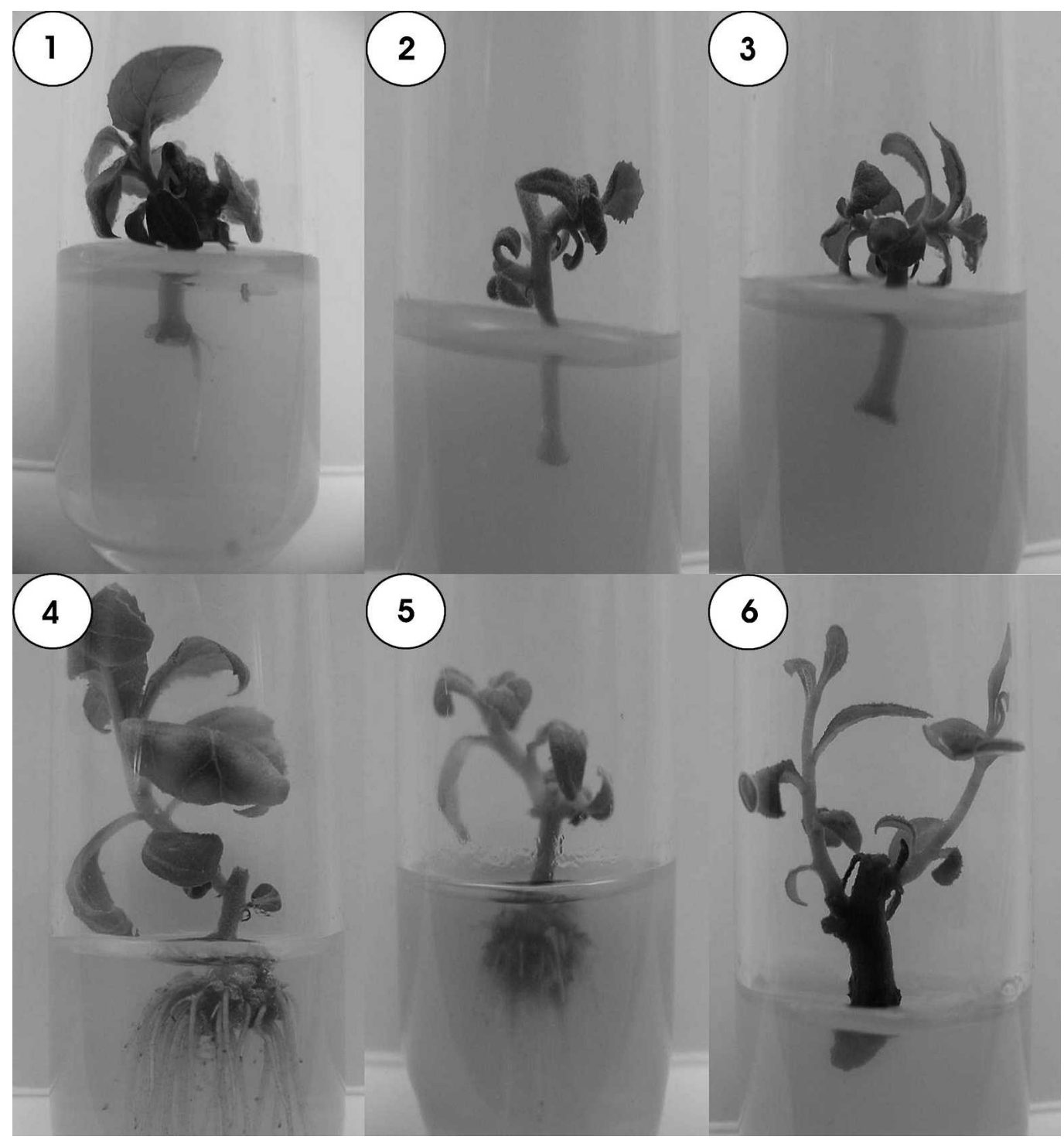

Fig. 5. Development of shoots on nodal bud explants of Eremanthus erythropappus following $45 \mathrm{~d}$ of incubation on Murashige and Skoog (1962) medium, supplemented with various concentrations (in $\mathrm{mg} \cdot \mathrm{L}^{-1}$ ) of plant growth regulators: (1) control; (2) $0.5 \mathrm{GA}_{3} ;(\mathbf{3}) 1.0 \mathrm{GA}_{3} ;(\mathbf{4}) 2.0 \mathrm{NAA} ;(\mathbf{5}) 2.0 \mathrm{NAA}+0.5 \mathrm{GA}$; and (6) $2.0 \mathrm{NAA}+1.0 \mathrm{GA}_{3}$. 


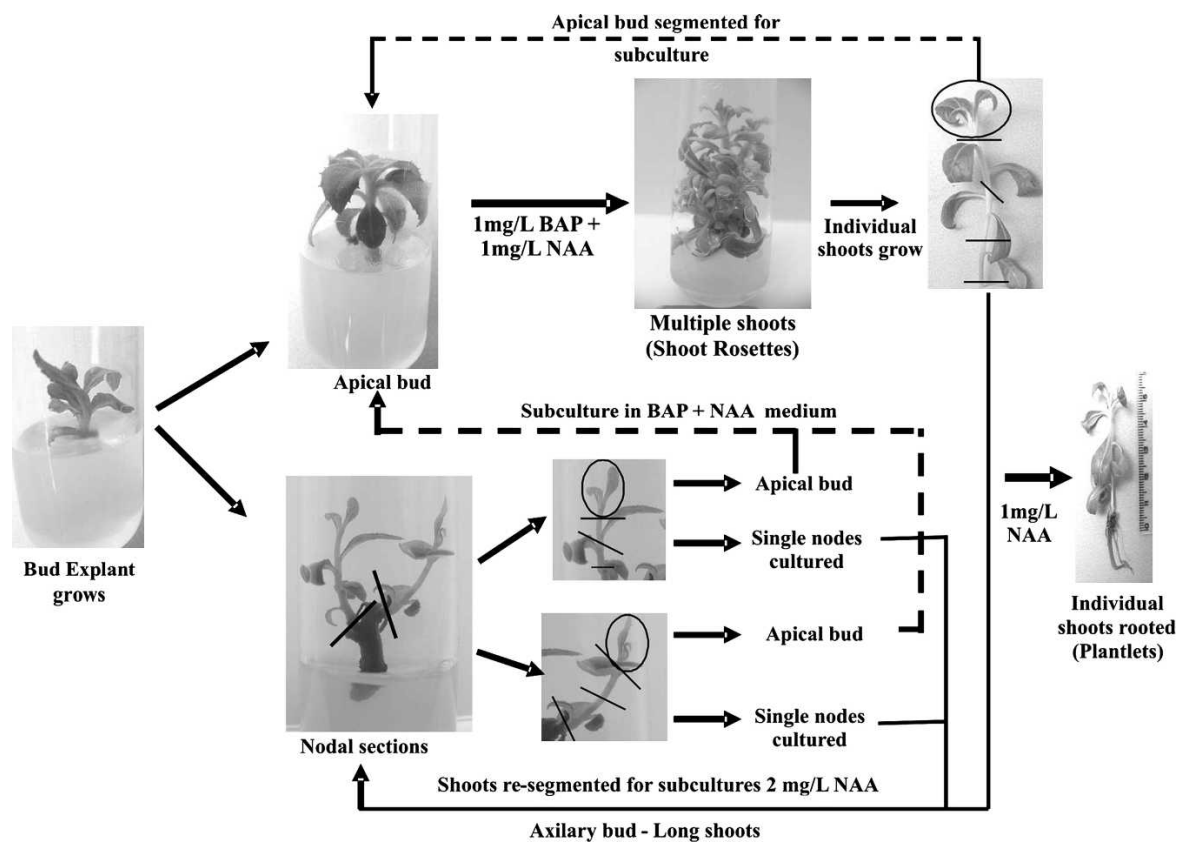

Fig. 6. General micropropagation protocol of Eremanthus erythropappus (DC.) MacLeish (candeia).

\section{Literature Cited}

Al-Wasel, A.S. 2000. Micropropagation of Acacia seyal Del. in vitro. J. Arid Environ. 46:425431.

Bais, H.P., J.B. Green, T.S. Walker, P.O. Okemo, and J.M. Vivanco. 2002. In vitro propagation of Spilanthes mauritiana DC., an endangered gation of Santonina canescens Lagasca and in vitro volatiles production by shoot explants. Plant Cell Tissue Organ Cult. 69:147-153.

Figueiredo, S.F.L., N. Albarello, and V.R.C. Viana. 2001. Micropropagation of Rollinia mucosa (Jacq.) Baill. In Vitro Cell. Dev. Biol. Plant 37:471-475.

George, E.F. 1996. Plant propagation by tissue culture: part 1-The Technology. Exegetics, Edington.

Gomes, G.A.C. 1999. Propagação in vitro de moreira (Maclura tinctoria). Universidade Federal de Lavras, Lavras, MSc Thesis. 92 p.

Hazra, S.K., S. Das, and A.K. Das. 2002. Sisal plant regeneration via organogenesis. Plant Cell Tissue Organ Cult. 70:235-240.

Mantell, S.H., J.A. Mathews, and R.A. McKee. 1994. Principles of plant biotechnology: an introduction to genetic engineering in plants. 5th ed. Blackwell Scientific, New York.

Murashige, T. and F. Skoog. 1962. A revised medium for rapid growth and bioassays with tobacco tissue cultures. Physiol. Plant. 15: 473-497.

Pérez, J.F.M. 2001. Sistema de manejo para candeia (Eremanthus erythropappus (DC.) MacLeish). Universidade Federal de Lavras, Lavras, MSc Thesis.

Sai, S.T., C.L. Keng, N. Pargini, and C.K.H. Teo. 2000. In vitro propagation of Typhonium flagelliforme (Lodd) Blume. In Vitro Cell. Dev. Biol. Plant 36:402-406.

medicinal herb, through axillary bud cultures. In Vitro Cell. Dev. Biol. Plant 38:598-601.

Carvalho, P.E.R. 1994. Espécies florestais Brasileiras: recomendações silviculturais, potencialidade e uso da Madeira. EMBRAPA-CNPF, Brasília.

Casado, J.P., M.C. Navarro, M.P. Utrilla, A. Martinez, and J. Jiménez. 2002. Micropropa-
Scarpa, G.M., M. Milia, and M. Satta. 2000. The influence of growth regulators on proliferation and rooting of in vitro propagated myrtle. Plant Cell Tissue Organ Cult. 62:175-179.

Teixeira, J.B. and P.A.S. Marbach. 2000. Fitohormônios. Universa 8:101-132. 